\title{
The role of the novel Th17 cytokine IL-26 in intestinal inflammation
}

\author{
J Dambacher, F Beigel, K Zitzmann, E N De Toni, B Göke, H M Diepolder, \\ C J Auernhammer, S Brand
}

- An additional video is published online only at http:// gut.bmi.com/content/vol58/ issueg

University Hospital MunichGrosshadern, Department of Medicine II, Ludwig-

Maximilians-University, Munich, Germany

Correspondence to: Dr S Brand, University Hospital Munich-Grosshadern,

Department of Medicine II, Ludwig-Maximilians-University

Munich, Marchioninistr 15,

D-81377 Munich, Germany; stephan.brand@

med.uni-muenchen.de

Revised 2 May 2008

Accepted 6 May 2008

Published Online First

15 May 2008

\begin{abstract}
Background and aims: Interleukin 26 (IL-26), a novel IL10-like cytokine without a murine homologue, is expressed in T helper 1 (Th1) and Th17 cells. Currently, its function in human disease is completely unknown. The aim of this study was to analyse its role in intestinal inflammation.
\end{abstract}

Methods: Expression studies were performed by reverse transcription-PCR (RT-PCR), quantitative PCR, western blot and immunohistochemistry. Signal transduction was analysed by western blot experiments and ELISA. Cell proliferation was measured by MTS (3-(4,5-dimethylthiazol2-yl)-5-(carboxymethoxyphenyl)-2-(4-sulfophenyl)-2Htetrazolium) assay. IL-26 serum levels were determined by an immunoluminometric assay (ILMA).

Results: All examined intestinal epithelial cell (IEC) lines express both IL-26 receptor subunits IL-20R1 and IL-10R2. IL-26 activates extracellular signal-related kinase (ERK)-1/ 2 and stress-activated protein kinase/c-Jun N-terminal kinase (SAPK/JNK) mitogen-activated protein (MAP) kinases, Akt and signal transducers and activators of transcription (STAT) 1/3. IL-26 stimulation increases the mRNA expression of proinflammatory cytokines but decreases cell proliferation. In inflamed colonic lesions of patients with Crohn's disease, an elevated IL-26 mRNA expression was found that correlated highly with the IL-8 and IL-22 expression. Immunohistochemical analysis demonstrated IL-26 protein expression in colonic T cells including Th17 cells expressing the orphan nuclear receptor ROR $\gamma \mathrm{t}$, with an increased number of colonic IL26-expressing cells in active Crohn's disease.

Conclusion: Intestinal cells express the functional IL-26 receptor complex. IL-26 modulates IEC proliferation and proinflammatory gene expression and its expression is upregulated in active Crohn's disease, indicating a role for this cytokine system in the innate host cell response during intestinal inflammation. For the first time, IL-26 expression is demonstrated in colonic ROR $\gamma$ t-expressing Th17 cells in situ, supporting a role for this cell type in the pathogenesis of Crohn's disease.

Interleukin 26 (IL-26), initially named AK155, was originally identified by subtraction hybridisation coupled with representational difference analysis as a gene upregulated in human $\mathrm{T}$ cells following infection with herpesvirus saimiri (HVS), with the capacity to transform these cells in culture. ${ }^{1}$ The IL-26 protein has $24.7 \%$ amino acid identity and $47 \%$ amino acid similarity to human IL-10. IL-26 is a member of the IL-10-like cytokine family composed of cytokines with limited homology to IL-10, including IL-10, IL-19, IL-20, IL-22, IL-24, IL-26, IL-28A, IL-28B and IL-29. IL-28A/B and IL-29 are also known as interferon $\lambda s$ (IFN $\lambda s$ ). IL-26 signals through a novel receptor complex consisting of the transmembrane proteins IL-20R1 and IL-10R2. ${ }^{2}$ In addition to cytokine-specific ligandbinding chains, IL-22, IL-26, IL-28A/B and IL-29 use a common second receptor chain (IL-10R2) for assembling their active receptor complexes and signalling.

The IL-26 gene is located on chromosome 12q14 in a cluster where IFN $\gamma$ and IL-22 are also positioned. IL-26 forms homodimers similarly to IL-10. ${ }^{1}$ IL-26 was originally described as a gene upregulated upon HVS infection in $\mathrm{T}$ cells ${ }^{1}$ but could also be detected in unstimulated fresh peripheral blood cells of healthy donors by reverse transcription-PCR (RT-PCR) analysis. ${ }^{1}$ Although the IL-10 transcript was detected in most cell lines of $\mathrm{T}$ or $\mathrm{B}$ cell lineage, the IL-26 transcript was rather specific for $\mathrm{T}$ cells. In another study, under basal conditions no IL-26 mRNA could be detected in monocytes, natural killer (NK) cells or B and $\mathrm{T}$ cells. ${ }^{3}$ Its expression could be induced only in NK cells and T cells upon stimulation with IL-2/IL-12 and anti-CD3 monoclonal antibody, respectively. ${ }^{3}$ This induction of IL-26 mRNA was observed specifically in activated memory cells (CD4 $4^{+}$ $\mathrm{CD}_{45 \mathrm{RO}^{+}}$) and during polarisation toward type 1 $\mathrm{T}$ helper (Th1) cells. ${ }^{3}$ A recent, preliminary study with in vitro differentiated $\mathrm{T}$ cells derived from healthy human blood donors suggests that Th17 cells also express IL-26 following stimulation with IL-23. ${ }^{4}$ Th17 cells are a newly discovered subset of inflammatory $\mathrm{T}$ cells ${ }^{5}$ that differentiate in humans under the influence of IL-1 $\beta$, IL-6, IL-21 and IL-23. ${ }^{6}$ They are characterised by the expression of the transcription factor $\mathrm{ROR} \gamma \mathrm{t}^{7}$ and the IL-23 receptor (IL-23R). ${ }^{8}$ They produce a specific pattern of cytokines and chemokines such as IL-17A, IL-17F, IL-21, IL-22 and CCL20. ${ }^{4} 10$ Th17 cells contribute to the pathogenesis of many inflammatory autoimmune diseases such as multiple sclerosis or rheumatoid arthritis (reviewed in Furuzawa-Carballeda et $\left.a l^{11}\right)$ and inflammatory bowel disease (IBD). ${ }^{12} 13$

Recent findings demonstrate that a heterodimer consisting of IL-20R1 and IL-10R2 functions as the IL-26 receptor. $^{214}$ This receptor complex is expressed particularly in epithelial cells such as keratinocytes and colonic epithelial cells. ${ }^{14}$ However, there is currently very limited information on the biological functions of IL-26. Interestingly, both IL-22 and IL-26 have been identified outside of mammals, and their organisation and synteny demonstrate that this cluster of cytokines is well conserved during evolution. ${ }^{15}$ However, in contrast to IL-22, no murine IL-26 homologue has been described so far, limiting the experimental opportunities to study the phenotypic 
consequences of IL-26 gene knockout and IL-26-mediated functions in murine models in vivo. Moreover, there are no studies on the effects of IL-26 in human disease published so far.

Given the IL-26 receptor expression in colonic epithelial cells ${ }^{14}$ and our recent findings on the important role of other IL-10-like cytokines such as IL-22, IL-28A and IL-29 in the regulation of intestinal epithelial cells (IECs) ${ }^{16}{ }^{17}$ and hepatic cells, ${ }^{18-20}$ we aimed to analyse in this study signal transduction pathways and specific biological functions mediated by IL-26 in IECs. Recently, we demonstrated that the IL-10-related cytokine IL-22, another Th1 and Th17 cytokine sharing the IL-10R2 subunit with IL-26 for signalling, is upregulated in intestinal inflammation and modulates intestinal barrier function. ${ }^{16}$ Therefore, we focused in this study on the role of IL-26 in IECs and in IBD.

\section{MATERIALS AND METHODS}

\section{Reagents}

The following antibodies were used in this study: anti-IL-26 and anti-IL-20R1 (R\&D Systems, Minneapolis, Minnesota, USA), anti-IL-10R2 (Acris Antibodies, Herford, Germany), anti-ROR $\gamma$ t (Abcam, Cambridge, UK), anti-pSTAT1 (BD Transduction Laboratories, Franklin Lakes, New York, USA), anti-pSTAT3 (Upstate Biotechnology, Lake Placid, New York, USA), antiSTAT1 and anti-STAT3 (Santa Cruz Biotechnology, Santa Cruz, California, USA). Antibodies against phosphorylated extracellular signal-regulated kinase (ERK)-1/2 (Thr183/ Tyr185), phosphorylated stress-activated protein kinase/c-Jun N-terminal kinase (SAPK/JNK; Thr183/Tyr185) and phosphoAkt (Ser473) were purchased from Cell Signaling (Beverly, Massachusetts, USA). Anti-ERK-1/2, anti-SAPK/JNK and antiAkt antibodies were also from Cell Signaling. Horseradish peroxidase (HRP)-linked antirabbit and antigoat secondary antibodies were purchased from Amersham (Arlington Heights, Illinois, USA) and Santa Cruz Biotechnology. Secondary antibodies for immunohistochemistry (AlexaFluor 488 or AlexaFluor 546 coupled and peroxidase coupled) were from Invitrogen (Karlsruhe, Germany) and Dako (Hamburg, Germany). Fluorescein isothiocyanate (FITC)-conjugated antigoat antibody was from Sigma-Aldrich (Taufkirchen, Germany) and antirabbit Cy-2 antibody was from Jackson Immuno Research (Suffolk, UK). Recombinant human IL-26 was obtained from R\&D Systems.

\section{Cell culture}

The human colorectal cancer-derived IEC lines SW480, SW620, Caco-2, HT-29, HCT116, T84 and DLD-1 were obtained from the American Type Culture Collection (Rockville, Maryland, USA). Cells were grown in Dulbecco's modified Eagle's medium (DMEM) containing $100 \mathrm{IU} / \mathrm{ml}$ penicillin, $100 \mu \mathrm{g} / \mathrm{ml}$ streptomycin and 10\% heat-inactivated fetal calf serum (FCS) from PAA (Pasching, Austria) in a humidified $5 \% \mathrm{CO}_{2}$ atmosphere at $37^{\circ} \mathrm{C}$.

\section{Reverse transcription-PCR}

RT-PCR was performed as previously described. ${ }^{21}$ Briefly, total RNA was isolated using Trizol reagent (Invitrogen). A $2 \mu \mathrm{g}$ aliquot of DNase-treated total RNA was reverse transcribed using the Qiagen Omniscript RT kit (Hilden, Germany). To control for genomic contamination, an identical parallel PCR was performed containing starting material that had not been reverse transcribed. The primers for the PCRs are shown in table 1 . The specificity of the PCR products was verified by sequencing.
Table 1 PCR primers used for RT-PCR analysis

\begin{tabular}{ll}
\hline IL-10R2 forward & 5'-ggctgaatttgcagatgagca-3' $^{\prime}$ \\
IL-10R2 reverse & $5^{\prime}$-gaagaccgaggccatgagg-3' \\
IL-20R1 forward & $5^{\prime}$-tacacccctcagctccaagact-3' \\
IL-20R1 reverse & $5^{\prime}$-gaaggaatacacagcctgccag-3' \\
IL-26 forward & $5^{\prime}$-ggcagaaattgagccactgt-3' \\
IL-26 reverse & $5^{\prime}$ - tccagttcactgatggctttg-3' \\
IL-6 forward & $5^{\prime}$-aaagaggcactggcagaaaa-3' \\
IL-6 reverse & $5^{\prime}$-gaggtgcccatgctacattt-3' \\
IL-8 forward & $5^{\prime}$-atgacttccaagctggccgtggct-3' \\
IL-8 reverse & $5^{\prime}$ 'tctcagccctcttcaaaaacttctc-3' \\
TNF $\alpha$ forward & $5^{\prime}$-atgagcactgaaagcatg-3' \\
TNF $\alpha$ reverse & $5^{\prime}$ 'tcacagggcaatgatccc-3' \\
SOCS-3 forward & $5^{\prime}$-ttctgatccgcgacagctc-3' \\
SOCS-3 reverse & $5^{\prime}$-tgcagagagaagctgcccc-3' \\
$\beta-$-Actin forward & $5^{\prime}$-gccaaccgcgagaagatga-3' \\
$\beta-$-Actin reverse & $5^{\prime}$-catcacgatgccagtggta-3'
\end{tabular}

IL, interleukin; RT-PCR, reverse transcription-PCR; SOCS-3, suppressor of cytokine signalling 3; TNF, tumour necrosis factor.

\section{Quantitative PCR}

Real-time PCR was performed with a Rotorgene RG-3000 cycler (Corbett Research, Sydney, Australia) using the Quantitect SYBR Green PCR Kit from Qiagen following the manufacturer's guidelines. Oligonucleotide primers (table 1) were designed not to amplify genomic DNA, according to the published sequences. The expression of each mRNA was normalised to $\beta$-actin expression in the respective cDNA preparation.

\section{Immunohistochemistry and immunocytochemistry}

Peroxidase staining of paraffin-embedded tissue slides was performed using standard protocols. Briefly, after deparaffinisation and demasking of antigens, endogenous peroxidases were blocked with $\mathrm{H}_{2} \mathrm{O}_{2}$. Slides were blocked with $10 \%$ normal serum and were incubated with avidin and biotin. Following incubation with the primary antibody overnight at $4^{\circ} \mathrm{C}$, slides were incubated with the secondary, biotin-conjugated antibody. Next, they were incubated with HRP-streptavidin, followed by incubation with the peroxidase substrate $3^{\prime}$-diaminobenzidine (DAB). Slides were counterstained with haematoxylin.

Double immunofluorescent staining (anti-ROR $\gamma \mathrm{t}$ and anti-IL26) of colonic tissue was performed on paraffin-embedded tissue. Following deparaffinisation, tissue was fixed for $1 \mathrm{~min}$ in a mixture of ice-cold acetic acid and methanol (1:1). Slides were washed with Tris-Tween and were blocked for $1 \mathrm{~h}$ with normal serum. The first primary antibody (anti-ROR $\gamma \mathrm{t}$ ) was incubated overnight at $4^{\circ} \mathrm{C}$ and the secondary, fluorochrome-coupled antibody was incubated for $1 \mathrm{~h}$ at room temperature. After washing, incubation with the second primary antibody (anti-IL26) and secondary antibody was performed in the same way.

Immunofluorescence staining of HT-29 cells was performed as described previously. ${ }^{22}$

\section{Signal transduction experiments, protein isolation, gel electrophoresis and immunoblotting}

The signal transduction experiments were performed in overnight serum-starved IEC lines as indicated. Cells were stimulated with $100 \mathrm{ng} / \mathrm{ml} \mathrm{IL-26,} \mathrm{unless} \mathrm{indicated} \mathrm{otherwise.} \mathrm{This}$ concentration was based on pilot experiments demonstrating a significantly greater effect of $100 \mathrm{ng} / \mathrm{ml} \mathrm{IL-26}$ for the activation of certain kinases than lower concentrations. Cells were solubilised in lysis buffer ${ }^{16}$ for $20 \mathrm{~min}$ and lysates were cleared by centrifugation at $10000 \mathrm{~g}$ for $20 \mathrm{~min}$. The protein concentration 
Figure 1 Interleukin 20 receptor 1 (IL-20R1) and IL-10R2 are expressed in intestinal epithelial cells (IECs). (A) mRNA expression of IL-20R1 and IL-10R2 as analysed by reverse transcription-PCR analysis of mRNA derived from IEC lines as indicated. IL-26 expression was not detected in any cell line (data not shown). (B, C) IL-20R1 and IL-10R2 proteins are expressed in IECs as demonstrated by western blot analysis in HT-29 and SW480 cells (left panels, $85 \mu \mathrm{g}$ protein/ lane) and by indirect immunofluorescence experiments (middle panels) in HT-29 cells using a fluorescein isothiocyanate (FITC)-labelled secondary antibody. Nuclei (blue) were stained with Hoechst 33342. In the negative control (right panels), the first antibody was omitted. GAPDH, glyceraldehyde phosphate dehydrogenase.

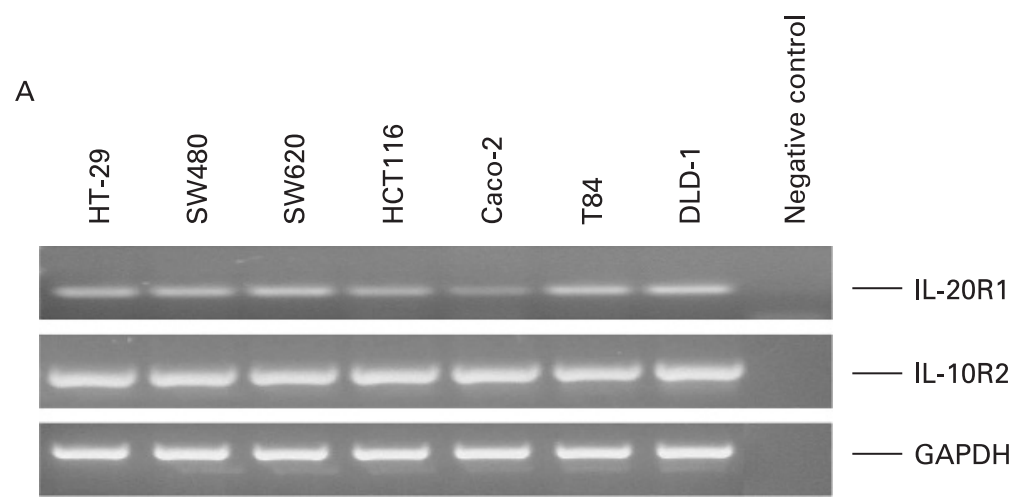

B
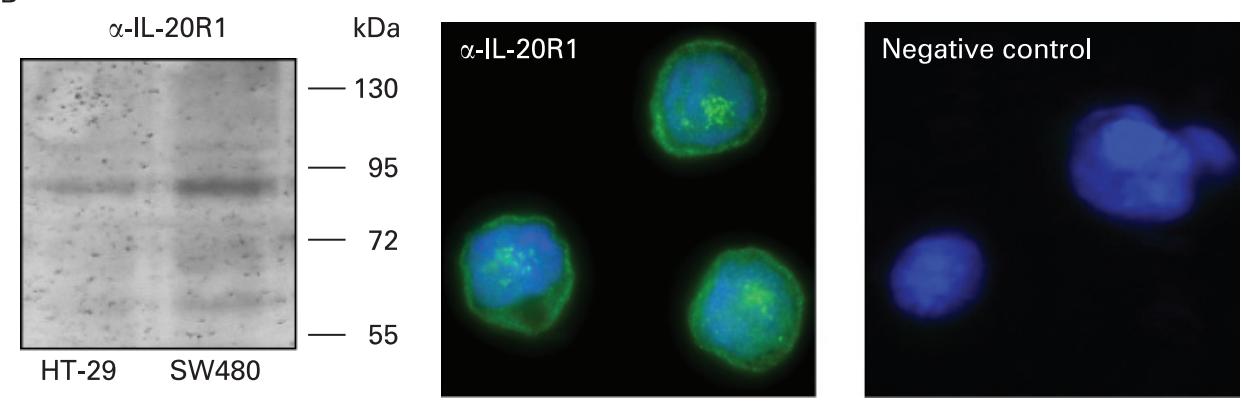

C

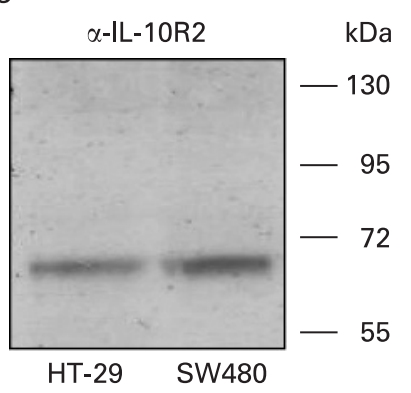

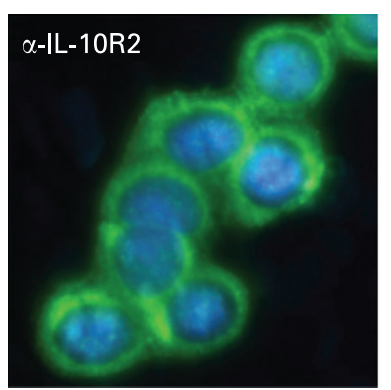

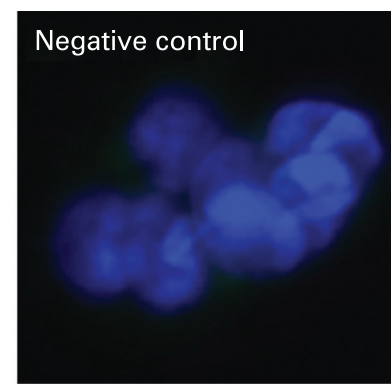

of each sample was quantified by the Bradford method. Immunoblotting was performed as previously described. ${ }^{23}$

\section{Enzyme-linked immunosorbent assay}

The BD OptEIA Human IL-8 Elisa Kit II (BD Biosciences, Bedford, Massachusetts, USA) was used for quantification of IL-8 release according to the manufacturer's instructions.

\section{IL-26 immunoluminometric assay (ILMA)}

Ninety-six-well plates (Nunc Maxisorb, Nunc, Wiesbaden, Germany) were incubated with a 1:1000 dilution of a monoclonal anti-IL-26-antibody for 7 days at $4^{\circ} \mathrm{C}$. After blocking with $2 \%$ non-fat milk for $1 \mathrm{~h}$ at room temperature, the plates were incubated with serum samples and different dilutions of recombinant human IL-26 overnight at $4^{\circ} \mathrm{C}$. Following incubation with a biotinylated polyclonal IL-26 antibody, neutravidin-HRP was added. Femtoglow (Michigan Diagnostics, Troy, Michigan, USA) was used as a chemoluminescent substrate and luminescence was measured in a microplate luminometer (Orion II, Berthold Detection Systems, Pforzheim, Germany).

\section{Cell proliferation assay}

HT-29 cells were seeded onto 96-well plates at a density of 5000 cells/well and grown for 1 day. After starvation in serum-free medium overnight, the cells were incubated with or without IL-26 (10 and $100 \mathrm{ng} / \mathrm{ml})$ in medium containing $0.1 \%$ FCS for $48 \mathrm{~h}$. Cell proliferation was determined using the CellTiter 96 Aqueous Non-Radioactive Cell Proliferation Assay (Promega, Madison, Wisconsin, USA) according to the manufacturer's instructions. Relative means (SEM) from three independent experiments are shown.

\section{Apoptosis assays}

Apoptosis assays were performed as described previously. ${ }^{24}$ For induction of TRAIL (tumour necrosis factor-related apoptosisinducing ligand)-mediated apoptosis, TRAIL at a concentration of $100 \mathrm{ng} / \mathrm{ml}$ was used, and for CD95-mediated cell death, ligandspecific anti-APO-1 monoclonal antibody at concentrations of 500 and $1000 \mathrm{ng} / \mathrm{ml}$ was used. Cells were incubated for $24 \mathrm{~h}$ with the respective ligands and with or without IL-26 (10 or $100 \mathrm{ng} / \mathrm{ml}$ ). Cells were harvested and were lysed in hypotonic lysis buffer ( $0.1 \%$ sodium citrate and $0.1 \%$ Triton X-100) containing $50 \mu \mathrm{g} / \mathrm{ml}$ propidium iodide, and were incubated at $4{ }^{\circ} \mathrm{C}$ overnight. The nuclei were then analysed for DNA content by flow cytometry.

\section{Colonic biopsies}

All participating patients with IBD were recruited by the IBD center of the University-Hospital Munich-Grosshadern (Germany) and gave written, informed consent prior to biopsy 
A

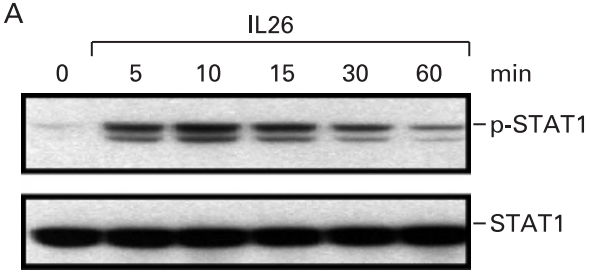

B
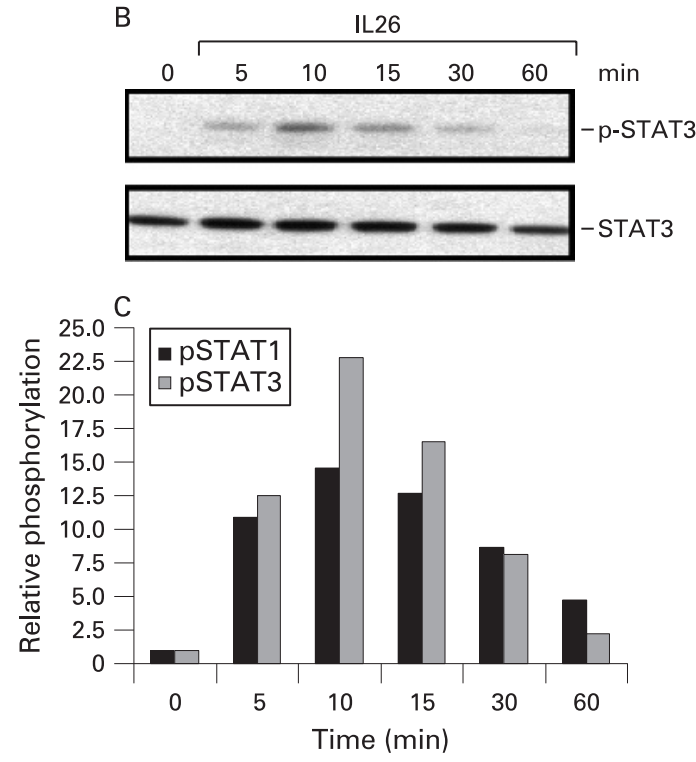

Figure 2 Interleukin 26 (IL-26) induces activation of the transcription factors signal transducers and activators of transcription 1 (STAT1) and STAT3. Following stimulation of HT-29 cells with IL-26 $(100 \mathrm{ng} / \mathrm{ml})$, increased phosphorylation was observed for STAT1 (A) and STAT3 (B). One representative experiment $(n=3)$ is shown. (C) Densitometric analysis of STAT1 and STAT3 phosphorylation.

sampling. The study was approved by the Ethics Committee of the Medical Faculty of the University of Munich. Biopsies were taken from patients with Crohn's disease and ulcerative colitis undergoing diagnostic colonoscopy. Patients with indeterminate colitis were excluded from the study. Demographic and clinical data were recorded by analysis of patient charts and a detailed questionnaire including an interview at the time of enrolment. The demographic data are summarised in table 2. The diagnosis of Crohn's disease or ulcerative colitis was determined according to established guidelines based on endoscopic, histopathological and radiological criteria.

From each patient, four biopsies were collected: two from macroscopically non-inflamed sites and two from macroscopically inflamed mucosa. IL-26 and IL-8 mRNA levels were measured in each individual biopsy. For quantification, the average IL-26 and IL-8 mRNA expression of the two non-inflamed biopsies was compared with the average expression in the two inflamed biopsies (all normalised to $\beta$-actin expression). In addition, IL-22 mRNA levels of these biopsies were available from a previous study ${ }^{16}$ and were included in the correlation analysis.

\section{Statistical analysis}

Statistical analysis was performed using two-tailed Student $t$ test. A p values $<0.05$ was considered as significant. Measured values that differed from the means by more than four times the standard deviation were considered as outliers and were not included in the statistical analysis.
A

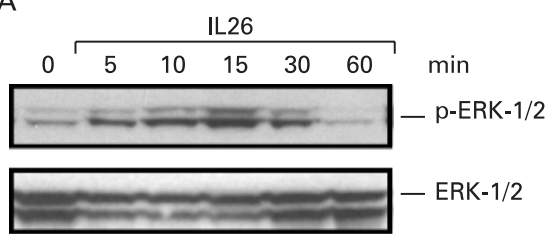

B

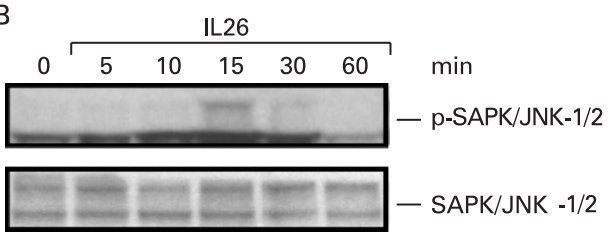

C
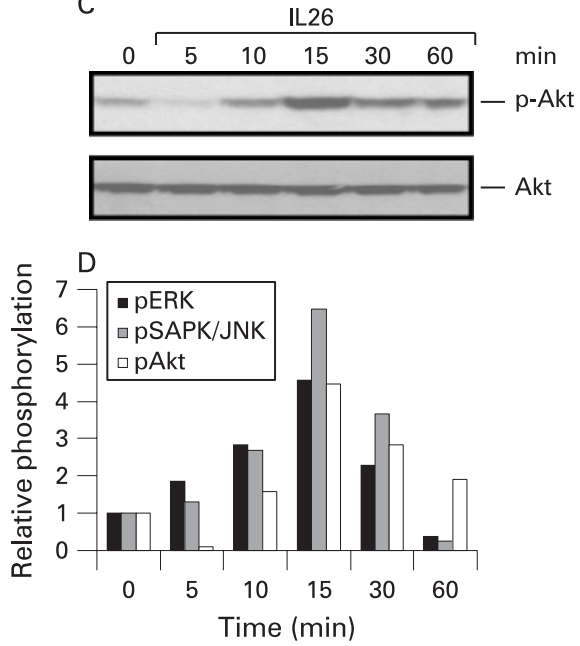

Figure 3 Interleukin 26 (IL-26) stimulation leads to extracellar signalregulated kinase (ERK)-1/2, stress-activated protein kinase/c-Jun Nterminal kinase (SAPK/JNK)-1/2 and Akt phosphorylation. IL-26 induces rapid activation of the mitogen-activated protein kinases ERK $(A)$ and SAPK/JNK (B) and of Akt $(C)$, reaching maximal phosphorylation levels after $15 \mathrm{~min}$. One representative experiment $(n=3)$ is shown. (D) Densitometric analysis of ERK, SAPK/JNK and Akt phosphorylation.

\section{RESULTS}

\section{IECs express the IL-26 receptor complex}

To utilise a cell system to study this ligand-receptor system, we first analysed if the IL-26 receptor complex consisting of IL-10R2 and IL-20R1 is expressed in IEC lines. RT-PCR for IL-10R2 and IL-20R1 mRNA was performed in several IEC cell lines (HT-29, SW480, SW620, HCT116, Caco-2, T84 and DLD1). RT-PCR analysis demonstrated IL-10R2 and IL-20R1 mRNA expression in all IEC lines tested (fig 1A), while IL-26 was not expressed (data not shown). The hepatic cell line HepG2 does not express IL-20R1 (data not shown) and served as a negative control cell line in the following signal transduction experiments. The expression of both IL-26 receptor subunits on the protein level was confirmed by western blot analysis of total protein extracts of HT-29 and SW480 cells (fig 1B,C; left panels) and by indirect immunofluorescence staining (fig 1B,C; middle panels) using specific antibodies against IL-20R1 and IL-10R2.

\section{IL-26 induces STAT1/3, ERK-1/2, SAPK/JNK-1/2 and Akt phosphorylation}

Next, we studied if the IL-26 receptor complex expressed by IECs is functional by analysing major intracellular signalling pathways. Since previous studies reported activation of STAT signalling by IL-26, ${ }^{214}$ we performed western blot analysis and 

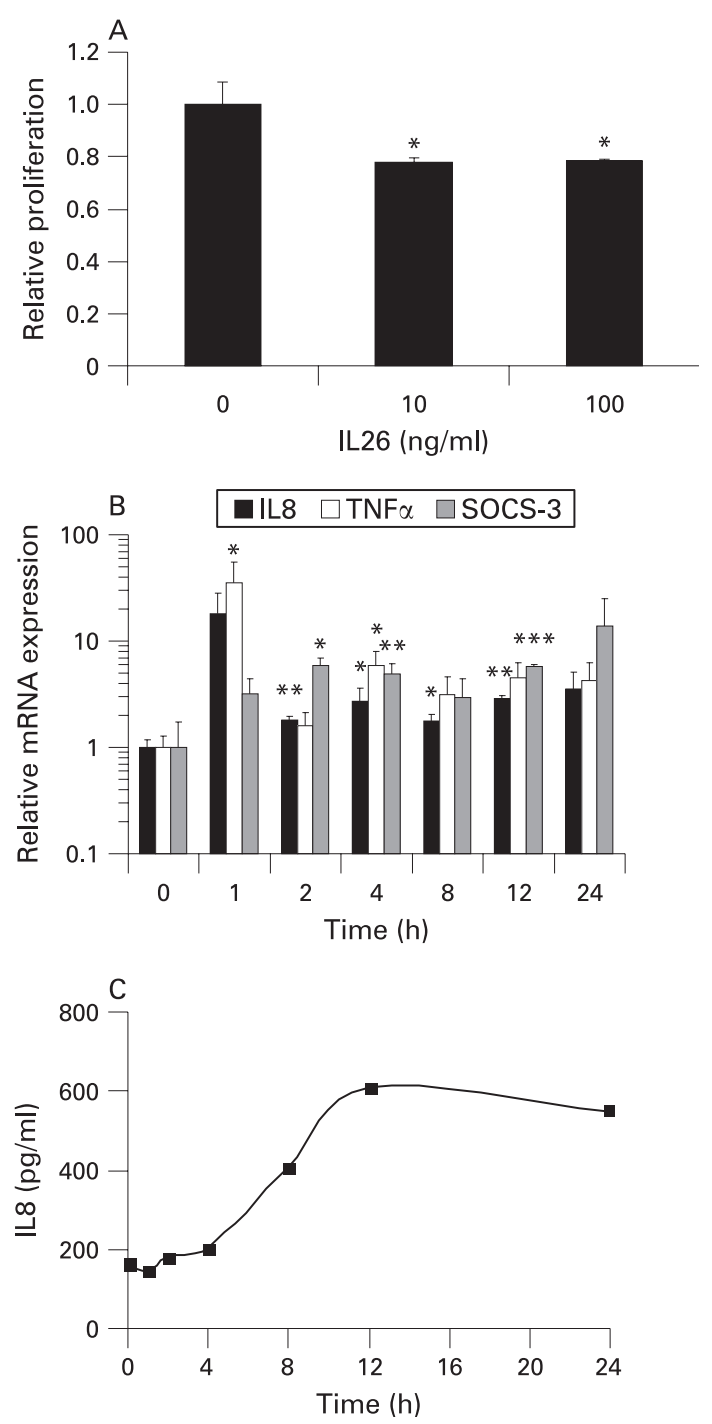

Figure 4 Interleukin 26 (IL-26) decreases cell proliferation and enhances mRNA expression of proinflammatory cytokines and suppressor of cytokine signalling 3 (SOCS-3). (A) Compared with medium-stimulated controls, 10 and $100 \mathrm{ng} / \mathrm{ml} \mathrm{IL-26} \mathrm{decreased} \mathrm{proliferation} \mathrm{of} \mathrm{HT-29} \mathrm{cells} \mathrm{(*} \mathrm{p}=0.05)$. The experiment was performed in triplicate. (B) Significant upregulation of IL-8, tumour necrosis factor $\alpha$ (TNF $\alpha$ ) and SOCS-3 mRNA expression after stimulation of HT-29 cells with $100 \mathrm{ng} / \mathrm{ml} \mathrm{IL-26}$ as determined by quantitative PCR. mRNA expression at the start of the experiment $(0 \mathrm{~h})$ was arbitrarily set to 1.0. Data are derived from two independent experiments. ${ }^{*} p<0.05,{ }^{* *} p<0.005,{ }^{* *} p<0.0005$. (C) IL-8 protein levels increase up to 3.7-fold and reach a maximum after $12 \mathrm{~h}$ of IL-26 stimulation. The IL-8 protein concentration was determined by ELISA.

investigated the influence of IL-26 on the phosphorylation levels of STAT1 and STAT3 in IECs. In comparison with basal STAT1 phosphorylation in unstimulated cells, a strong STAT1 tyrosine phosphorylation was observed upon IL-26 stimulation starting 5 min after cytokine stimulation (fig 2A). IL-26 also induced tyrosine phosphorylation of STAT3 which was strongest after 10 min of stimulation (fig 2B). Densitometric analysis of the phosphorylation blots demonstrated a 14.5- and 22.8-fold increase in phosphorylation for STAT1 and STAT3, respectively (fig 2C). In contrast, in HepG2 cells, which lack the IL-20R1 subunit, no STAT activation was detected after IL-26 stimulation, demonstrating that the IL-20R1 subunit is essential for IL-26 signalling (data not shown). In addition, ERK-1/2 mitogen-acivated protein (MAP) kinases (fig $3 \mathrm{~A}$ ) and-to a lesser degree-SAPK/JNK kinases (fig 3B) were transiently activated by $100 \mathrm{ng} / \mathrm{ml}$ IL-26. Moreover, IL-26 induced phosphorylation of Akt (fig 3C). The maximum ERK, SAPK/JNK and Akt activation was 15 min after cytokine stimulation (fig 3D), whereas the maximal STAT1/3 phosphorylation levels were already reached $10 \mathrm{~min}$ after IL-26 stimulation (fig 2C).

\section{IL-26 decreases proliferation but does not influence apoptosis in IECs}

Recently, we demonstrated that activation of ERK MAP kinases, Akt and STAT proteins following stimulation with chemokines or IL-22 mediates IEC proliferation, ${ }^{1625}{ }^{26}$ while STAT activation following IL-28A and IL-29 stimulation mediates antiproliferative signals in IECs. ${ }^{7}{ }^{7}$ Therefore, we analysed the effect of IL-26 on IEC proliferation in the following experiments. Similar to IL-28A and IL-29, ${ }^{17}$ IL-26 had a modest antiproliferative effect on IECs. Compared with cytokine-free medium-stimulated controls, IEC proliferation was diminished by $22 \%$ following stimulation with 10 and $100 \mathrm{ng} / \mathrm{ml} \mathrm{IL-26}$ (fig 4A, $p=0.05$ ). However, IL-26 did not significantly influence apoptosis induced by TRAIL or by anti-APO-1 treatment in HT-29 cells (data not shown).

\section{IL-26 increases expression of proinflammatory cytokines}

After demonstrating that the IL-26 receptor complex is functional in IECs, we next examined transcriptional targets of this cytokine. Previously, we identified SOCS-3 as a STAT1/ 3-dependent gene. ${ }^{27}$ Therefore, we analysed SOCS-3 mRNA levels in IECs stimulated with IL-26. As shown in fig 4B, IL-26 treatment induced SOCS-3 mRNA expression significantly $(p<0.005)$, reaching a maximum increase of 13.8 -fold after $24 \mathrm{~h}$. Next, we analysed the role of IL-26 on the transcriptional regulation of the proinflammatory cytokines tumour necrosis factor $\alpha$ (TNF $\alpha$ ), IL-8 and IL-6, three major inflammatory mediators in IECs, as downstream readout of IL-26-mediated gene expression. While IL- 6 mRNA expression did not change significantly after IL-26 stimulation (data not shown), IL-26 enhanced TNF $\alpha$ and IL-8 mRNA expression 35.1- and 18.0-fold, respectively $(p<0.05)$, as measured by quantitative PCR (fig $4 B)$. Similarly, we measured a 3.7 -fold increased IL-8 protein release by ELISA following IL-26 stimulation (fig 4C).

\section{IL-26 mRNA expression is increased in the inflamed colonic mucosa of patients with Crohn's disease}

Since we established that IL-26 upregulates the expression of proinflammatory cytokines in IECs, we next analysed by real-time PCR its expression in intestinal inflammation in vivo. This analysis included a total of 88 biopsy samples taken from 22 different patients with IBD (Crohn's disease: $\mathrm{n}=12$; ulcerative colitis: $n=10$ ). The demographics of these patients and the anatomic segment of the biopsy sampling are summarised in table 2 .

Ileal and colonic biopsies were taken from sites with endoscopically (macroscopic) inflamed colonic mucosa and were compared with those of endoscopically non-inflamed colonic mucosa taken from the same 22 patients. In patients with Crohn's disease, the colonic IL-8 mRNA expression, which was determined as a standard inflammatory marker, was 5.9-fold higher in the inflamed biopsy samples compared with uninflamed biopsies $(\mathrm{p}<0.05$; table 2$)$.

Similarly, we measured increased IL-26 mRNA expression in inflamed colonic biopsies compared with non-inflamed colonic tissue (increase between 1.1- and 15.0-fold; table 2). The increases in IL-8 and IL-26 expression in inflamed biopsies were 
Table 2 Demographic data of patients and results of the cytokine expression analysis using quantitative PCR

\begin{tabular}{|c|c|c|c|c|c|c|c|c|c|}
\hline \multirow[b]{2}{*}{$\begin{array}{l}\text { Patient } \\
\text { number }\end{array}$} & \multirow[b]{2}{*}{ Sex } & \multirow{2}{*}{$\begin{array}{l}\text { Age at } \\
\text { diagnosis } \\
\text { (years) }\end{array}$} & \multirow{2}{*}{$\begin{array}{l}\text { Disease } \\
\text { duration } \\
\text { (years) }\end{array}$} & \multirow[b]{2}{*}{ Current medication } & \multicolumn{2}{|c|}{ Anatomic site of biopsy sampling } & \multirow{2}{*}{$\begin{array}{l}\text { IL-26 } \\
\text { expression } \\
\text { inflamed vs } \\
\text { non-inflamed }\end{array}$} & \multirow{2}{*}{$\begin{array}{l}\text { IL-8 expression } \\
\text { inflamed vs } \\
\text { non-inflamed }\end{array}$} & \multirow{2}{*}{$\begin{array}{l}\text { IL-22 } \\
\text { expression } \\
\text { inflamed vs } \\
\text { non-inflamed }\end{array}$} \\
\hline & & & & & Non-inflamed & Inflamed & & & \\
\hline CD2 & $M$ & 18 & 16 & Mesalazine, AZA & Descending colon & Descending colon & 8.30 & 11.67 & 3.67 \\
\hline CD3 & $\mathrm{F}$ & 25 & 15 & None & Colon & Colon & 2.31 & 1.50 & 0.32 \\
\hline CD4 & $\mathrm{F}$ & 28 & 1 & AZA & Caecum* & Terminal ileum* & 6.22 & 11.08 & 1.92 \\
\hline CD6 & $\mathrm{F}$ & 29 & 22 & None & Descending colon & Descending colon & 0.52 & 1.41 & 2.81 \\
\hline CD7 & $\mathrm{F}$ & 18 & 5 & MTX & Caecum* & $\begin{array}{l}\text { Terminal ileum/ } \\
\text { ileocaecal valve* }\end{array}$ & 15.03 & 31.12 & 13.58 \\
\hline CD8 & M & 36 & 17 & AZA & Transverse colon & Transverse colon & 0.85 & 2.24 & 3.07 \\
\hline $\operatorname{CD9}$ & M & 50 & 1 & None & Ascending colon* & Terminal ileum* & 1.86 & 0.97 & ND \\
\hline CD10 & M & 36 & 17 & Corticosteroids & Caecum* & Terminal ileum* & 3.72 & 1.45 & 1.37 \\
\hline UC1 & $\mathrm{F}$ & 65 & 5 & Corticosteroids & Sigmoid* & Rectum* & 1.77 & 6.97 & 0.52 \\
\hline UC2 & $\mathrm{M}$ & 48 & 1 & Mesalazine, budenosid & Descending colon & Descending colon & 1.78 & 2.37 & 0.97 \\
\hline UC3 & M & 74 & 2 & AZA & rectum & Rectum & 0.78 & 0.94 & 0.72 \\
\hline UC4 & $\mathrm{F}$ & 39 & 5 & None & Transverse colon & Transverse colon & 2.75 & 2.01 & 3.25 \\
\hline UC5 & $M$ & 39 & 3 & None & Caecum* & Rectum* & 8.66 & 8.12 & 5.74 \\
\hline UC6 & M & 57 & 6 & $\begin{array}{l}\text { AZA, corticosteroids, } \\
\text { mesalazine }\end{array}$ & Caecum & Caecum & 0.36 & 2.64 & ND \\
\hline UC7 & $\mathrm{M}$ & 36 & 6 & 6-MP & Sigmoid & Sigmoid & 1.63 & 5.82 & 1.82 \\
\hline UC8 & $\mathrm{F}$ & 34 & 4 & None & Sigmoid & Sigmoid & 5.73 & 3.27 & 2.42 \\
\hline UC9 & B & 34 & 8 & $\begin{array}{l}\text { 6-MP, mesalazine, } \\
\text { corticosteroids }\end{array}$ & Caecum* & Ascending colon* & 1.72 & 0.49 & 1.76 \\
\hline UC10 & $M$ & 34 & 9 & MTX & Sigmoid* & Rectum* & 0.89 & 2.44 & 0.84 \\
\hline $\begin{array}{l}\text { Average } \\
\text { (SEM) }\end{array}$ & & $46.0(4.6)$ & $4.9(0.8)$ & & Ulcerative colitis & & $2.61(0.78)$ & $3.31(0.83)$ & $2.00(0.55)$ \\
\hline
\end{tabular}

The current medical therapy and the anatomic site, from which the samples were taken, are given for all patients. Biopsy sampling for inflamed and non-inflamed lesions was aimed to be taken in the same colonic or ileal segment. This was not possible in patients marked with an asterisk due to severe inflammation in the whole anatomic segment. Therefore, biopsies from a bordering (non-inflamed) segment were included for comparison.

AZA, azathioprine; F, female; IFX, infliximab; M, male; 6-MP, 6-mercaptopurine; MTX, methotrexate; ND, not determined

highly related to each other (correlation coefficient $r=0.96$; fig $5 \mathrm{~A}$ ). Although there was also a high correlation between IL-8 and IL-26 mRNA expression in patients with ulcerative colitis $(r=0.79$; fig $5 B)$ and IL-8 expression was significantly increased up to 8.1-fold in the inflamed tissue ( $p=0.02$; table 2$)$, the difference in IL-26 mRNA expression in inflamed and noninflamed biopsies did not reach statistical significance $(p=0.08)$ in patients with ulcerative colitis.

Next, we compared IL-26 expression with the expression of IL-22, another IL-10-like cytokine expressed in Th17 cells. IL-22 expression data were available from a previous study. ${ }^{16}$ Interestingly, the increase in IL-26 expression in inflamed colonic tissue correlated highly with the increase in IL-22 expression (fig 5C,D) in patients with Crohn's disease and ulcerative colitis ( $r=0.81$ for Crohn's disease; $r=0.89$ for ulcerative colitis).

\section{IL-26 serum protein expression is higher in patients with Crohn's disease compared with controls}

In addition, we developed an ILMA as described in the Materials and methods section for the detection of IL-26 protein using a monoclonal IL-26 antibody for capturing and a polyclonal IL-26 antibody for detection. To determine if the increased colonic IL-26 mRNA expression in patients with Crohn's disease is mirrored by an increased IL-26 serum expression, we analysed the IL-26 protein expression in the sera of 40 patients with Crohn's disease and 39 unrelated controls by ILMA. Analysis revealed significantly higher IL-26 serum levels in patients with Crohn's disease (mean concentration $2.42 \mathrm{ng} / \mathrm{ml}$, range 0.79-17.56) in comparison with control patients (mean concentration $1.17 \mathrm{ng} / \mathrm{ml}$, range 0.56-4.17; $\mathrm{p}<0.01$ vs Crohn's disease).

\section{Intestinal ROR $\gamma$ t-expressing Th17 cells produce IL-26 and their} number is increased in active Crohn's disease

To analyse further expression of IL-26 in colonic tissue in situ and to clarify which cells produce IL-26, we performed a detailed immunohistochemical analysis for IL-26 in inflamed and noninflamed colonic tissue of patients with Crohn's disease. As shown in the representative images of this analysis in fig 6 $\mathrm{A}$ and B, IL-26 is expressed in infiltrating immune cells but not in epithelial cells. Importantly, the number of IL-26-expressing cells in inflamed colonic tissue of patients with Crohn's disease (fig 6D,E) was higher than in uninflamed tissue (fig 6A,B) which is consistent with our quantitative PCR analysis of colonic IL-26 mRNA expression (table 2).

A preliminary study of Th17 cells from healthy donors differentiated from peripheral $\mathrm{T}$ cells in vitro suggested Th17 cells as the source of IL-26 production. ${ }^{4}$ To clarify if colonic Th17 cells express IL-26 in situ, we performed co-staining using specific antibodies directed against IL-26 and ROR $\gamma \mathrm{t}$, a transcription factor that is specifically expressed in Th17 cells. ${ }^{7}$ Examples of this immunohistochemical analysis shown in fig 7 
Figure 5 Intestinal interleukin 26 (IL-26) mRNA expression is upregulated in inflammatory bowel disease and correlates with IL-8 and IL-22 mRNA expression. $(A, B)$ The increase of IL-26 mRNA expression in inflamed colonic and ileal biopsies (in comparison with uninflamed tissue) correlated highly with the respective IL-8 mRNA expression in Crohn's disease (CD) $(A, r=0.96)$ and ulcerative colitis (UC) $(B, r=0.79)$. (C, D) High correlation between the increase of mRNA expression of IL-26 and IL-22, another IL-10-related T helper 17 (Th17) cytokine, in inflamed intestinal biopsies from patients with (C) CD and (D) UC $(r=0.81$ and 0.89 , respectively).
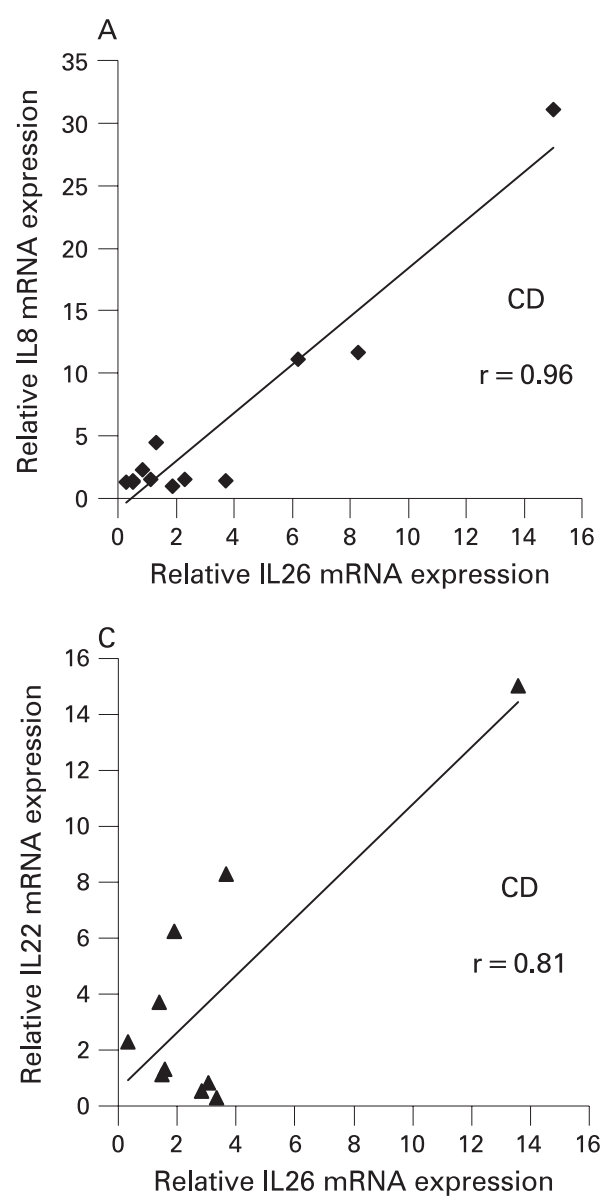
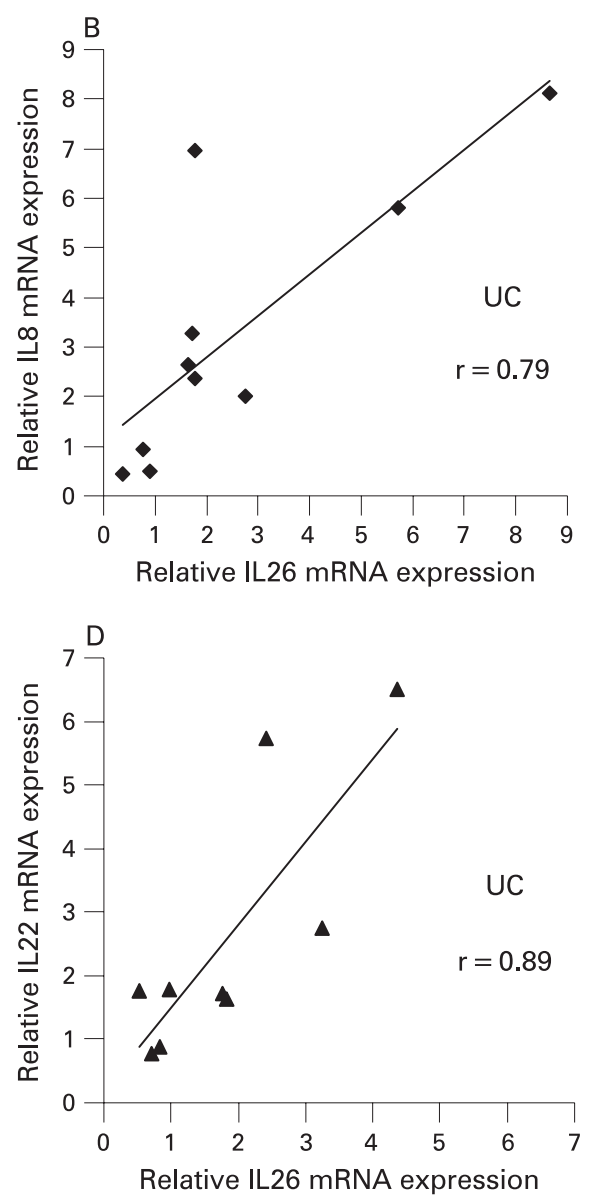
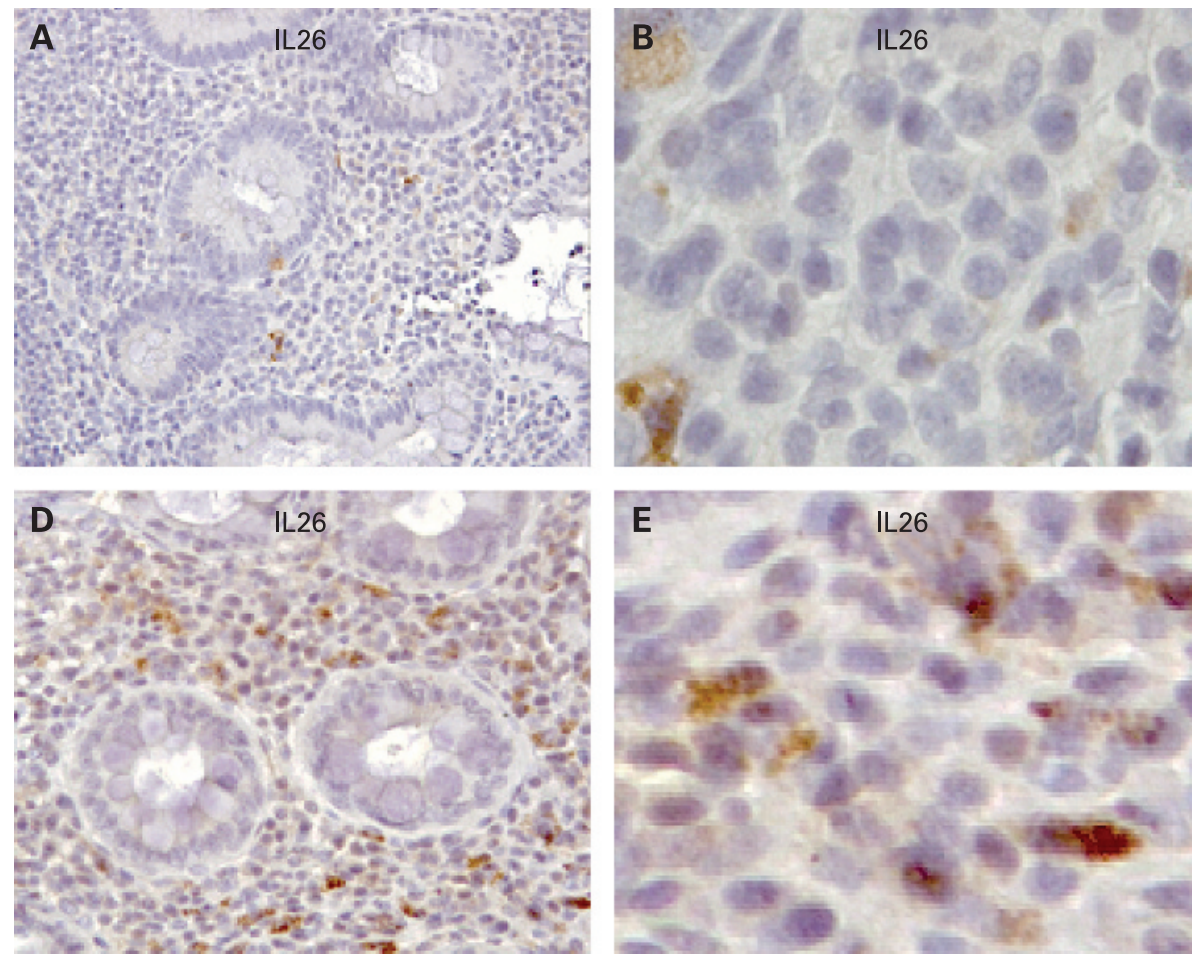

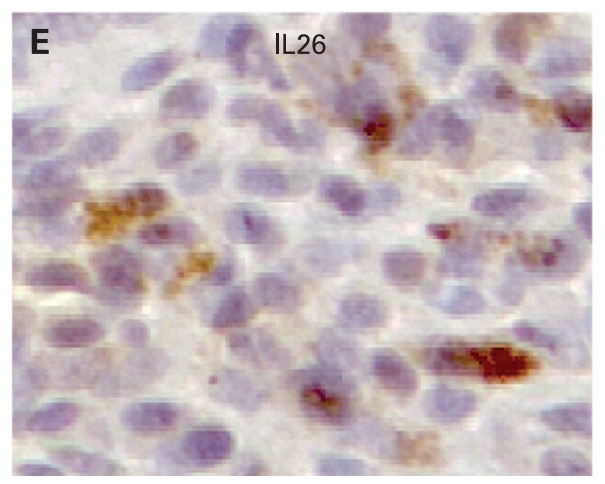

Figure 6 The number of infiltrating interleukin 26 (IL-26)-positive immune cells is increased in active Crohn's disease. Representative immunoperoxidase analysis of IL-26 expression of uninflamed colonic tissue (A-C) and inflamed colonic tissue (D-F) taken from a patient with Crohn's disease. In the negative controls, the secondary antibody was omitted. Original magnification was $\times 20(A, C, D, F),(B, E) D e t a i l$ from $A$ and $D$, respectively. 

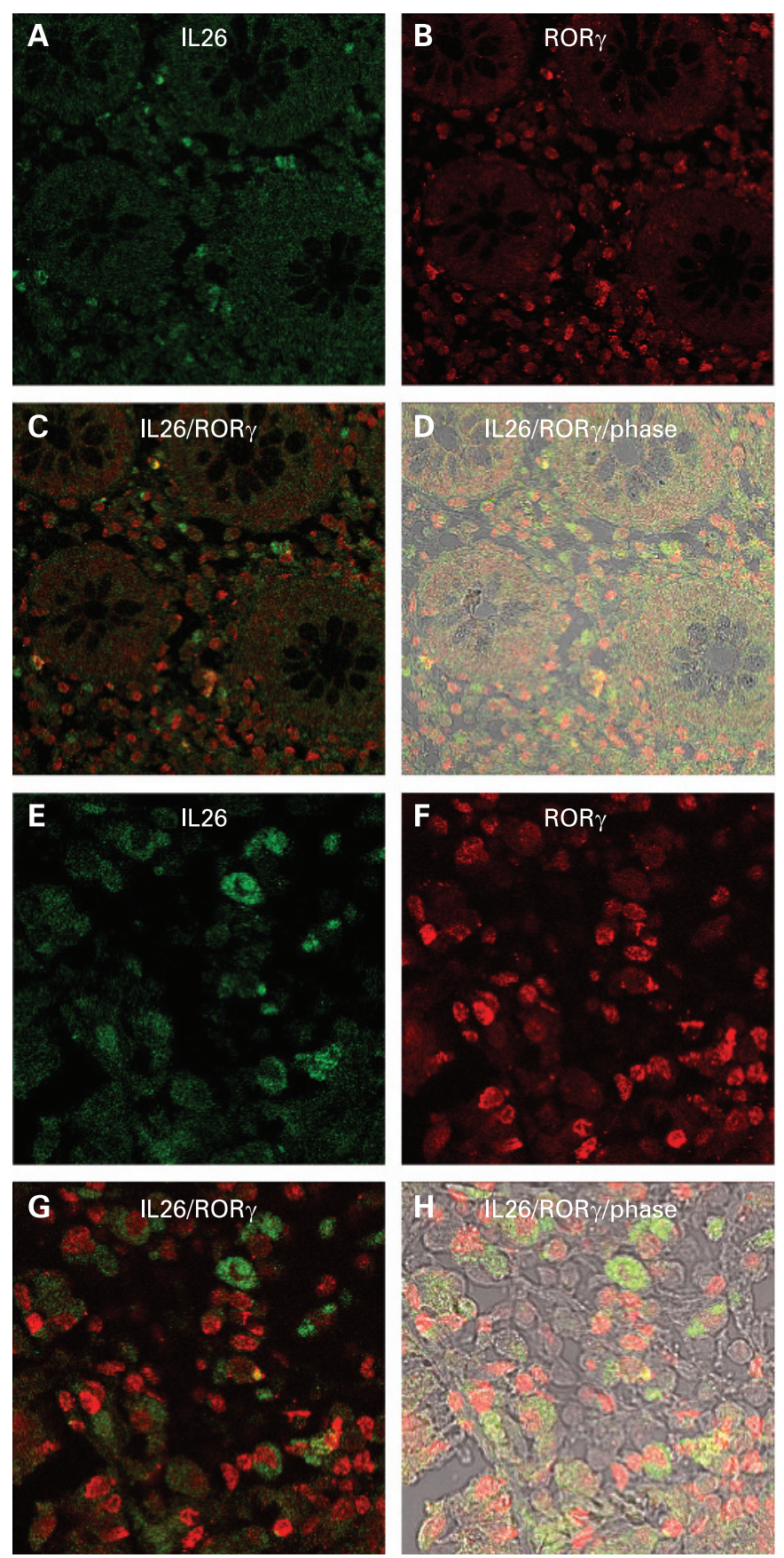

Figure 7 Interleukin 26 (IL-26) is expressed in colonic ROR $\gamma$ texpressing T helper 17 (Th17) cells in active Crohn's disease. Immunofluorescence analysis of colonic IL-26 (A, E) and ROR $\gamma \mathrm{t}$ expression $(B, F)$ in colonic tissue in situ from patients with Crohn's disease. (C) (merged image of $A$ and $B$ ) and $(G)$ (merged image of $E$ and F) demonstrate that a number of ROR $\gamma \mathrm{t}^{+} \mathrm{Th} 17$ cells also express IL-26. $\mathrm{D}$ and $\mathrm{H}$ are images from $\mathrm{C}$ and $\mathrm{D}$ overlaid with the phase contrast microscopic image from the same section, demonstrating the lack of IL-26 expression in colonic intestinal epithelial cells.

demonstrate that a considerable number of ROR $\gamma$ t-expressing Th17 cells also express IL-26, while, however, not all Th17 cells are producers of IL-26. One difficulty of this analysis is the fact that ROR $\gamma$ t and IL-26 are expressed in two different cell compartments (ROR $\gamma$ t in the nucleus and IL-26 in the cytosol). Therefore, ROR $\gamma$ t-expressing Th17 cells, which are imaged only on a cytosolic cross-section, will not appear ROR $\gamma$ t-positive on such a cross-sectional image. To demonstrate the expression of ROR $\gamma t$ and IL-26 in different cell compartments, we performed reconstructional analysis of cross-sectional images of single cells. A video sequence of such sequential cross-sections of a single cell imaged by confocal microscopy can be found in the Supplemental materials online (Video file S1). Frames of this video sequence are shown in fig. $8 \mathrm{~A}-\mathrm{F}$, demonstrating the nuclear expression of ROR $\gamma \mathrm{t}$ and the cytosolic expression of IL-26. Interestingly, cross-sections taken outside of the nucleus (fig 8E,F) appear not to be stained for ROR $\gamma$ t. Only in Th17 cells with very strong IL-26 and ROR $\gamma$ t expression did IL-26 and $\mathrm{ROR} \gamma \mathrm{t}$ staining appeared to "co-localise" in the perinuclear region (fig $8 \mathrm{~F}-\mathrm{I}$ ).

\section{DISCUSSION}

This study represents the first report demonstrating a role for IL-26 in human disease. IL-26 is a novel member of the IL-10-like cytokine family and shares with IL-10 the IL-10R2 subunit for signalling. While IL-10 has anti-inflammatory properties, we here demonstrate that IL-26 has proinflammatory functions in IECs and is upregulated in IBD. Recently, our group also demonstrated proinflammatory functions for IL-22, another IL-10-like cytokine in IECs. ${ }^{16}$ Similar to IL-22, ${ }^{16}$ IL-26 upregulates the gene expression of proinflammatory cytokines in IECs. In addition, we demonstrate functional IL-26 receptor expression in IECs. IL-26 activates ERK and SAPK/JNK MAP kinases, Akt and STAT proteins in IECs, which are the major signalling pathways of other proinflammatory cytokines with increased expression in IBD such as IL-22 ${ }^{16}$ and IL-31. ${ }^{22}$ In contrast, cell lines such as HepG2, which do not express the IL-20R1 subunit, are not responsive to IL-26 treatment.

It has been shown that activated $T$ cells are a major source of IL-26 production. ${ }^{13}$ Depending on the $\mathrm{T}$ cell source of cytokine production, cytokines have been differentiated in Th1 and Th2 cytokines. Previous studies demonstrated an induction of IL-26 production particularly in Th1 cells. ${ }^{3}$ Crohn's disease is considered to represent a Th1- and Th17-mediated intestinal inflammation, while ulcerative colitis has, at least to some degree, features of Th2-mediated colitis. ${ }^{28}{ }^{29}$ Consistent with this observation, in our study the relative upregulation of IL-26 expression (compared with uninflamed tissue) was more pronounced in inflamed lesions of patients with Crohn's disease compared with patients with ulcerative colitis. Moreover, colonic IL-26 mRNA expression correlated strongly with IL-8 and IL-22 mRNA expression, confirming IL-26 as a marker of intestinal inflammation.

Our detailed immunohistochemical analysis revealed for the first time IL-26 protein expression in situ. There was an increased number of IL-26-expressing cells in active Crohn's disease which correlated with the results of our quantitative PCR analysis of colonic biopsy tissue taken from inflamed and uninflamed mucosa affected by Crohn's disease. IL-26 expression was found in infiltrating intestinal $\mathrm{T}$ cells including ROR $\gamma$ t-expressing Th17 cells, but not in primary IECs. This is of particular interest, since very recent evidence suggests that Th17 cells contribute to the pathogenesis of IBD, particularly Crohn's disease. ${ }^{28}$ This is also supported by a recent genomewide association study demonstrating IL23R, which is expressed by Th17 cells, to be a Crohn's disease susceptibility gene. ${ }^{30}$ We recently confirmed $I L 23 R$ as an IBD susceptibility gene in the German population. ${ }^{31}$ Interestingly, we demonstrated that the genetic risk for Crohn's disease mediated by IL23R is directly linked to the expression of the proinflammatory cytokine IL-22 $2^{32}$ which is also expressed in Th17 cells. ${ }^{4}$ Moreover, we and others 

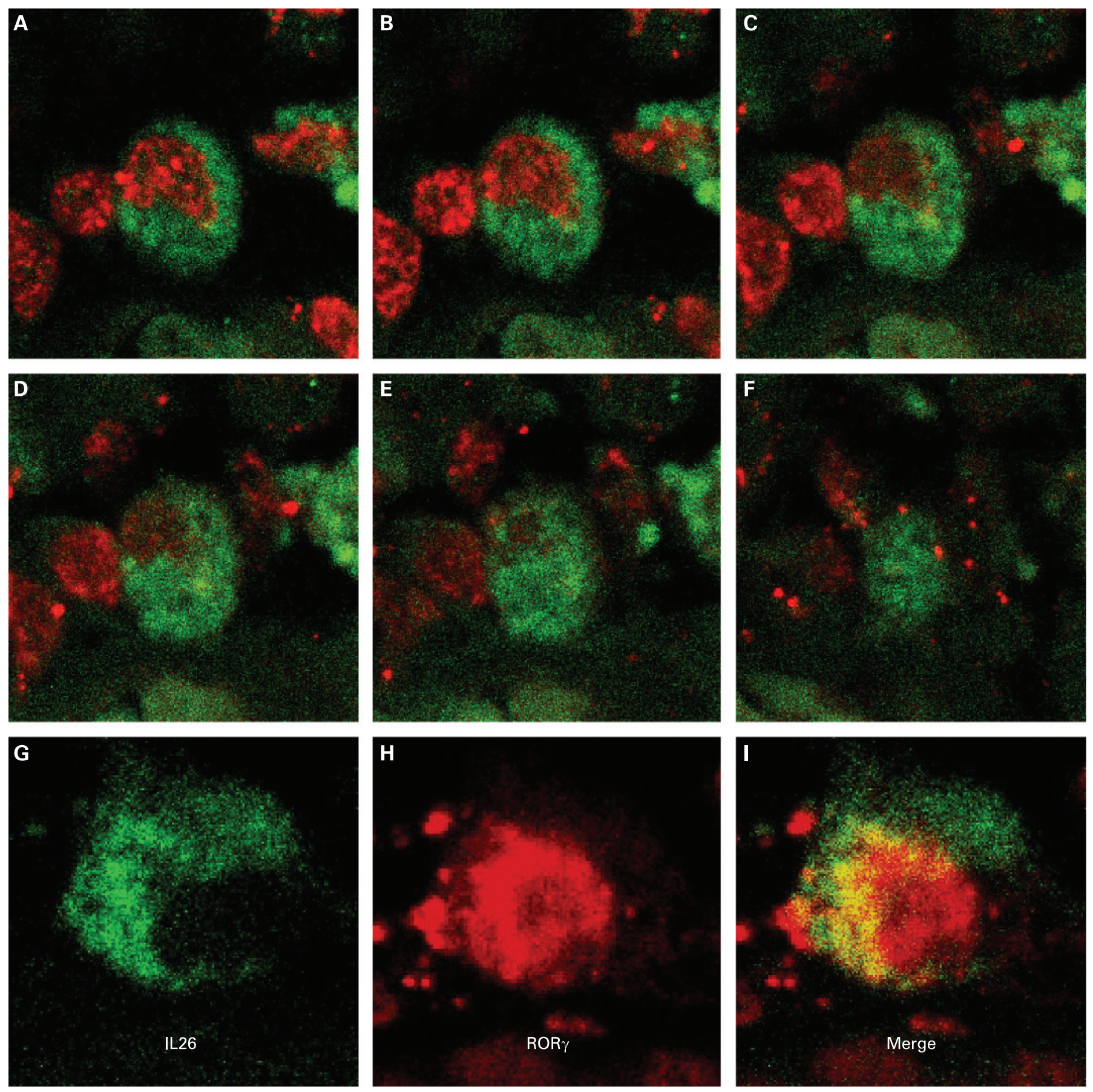

Figure 8 Interleukin 26 (IL-26) and ROR $\gamma$ t expression are confined to different cellular compartments. (A-F) Sequential single cell images derived from cross-sectional confocal microscopic imaging using an anti-IL-26 antibody (secondary antibody AlexaFluor 488 labelled) and anti-ROR $\gamma \mathrm{t}$ antibody (secondary antibody AlexaFluor 546 coupled) demonstrating nuclear expression of ROR $\gamma \mathrm{t}$ (red) and cytosolic expression of IL-26 (green). The corresponding video file can be found in the Supplementary data (Video file S1) online. (G-I) Only in cells with very high IL-26 (G) and ROR $\gamma \mathrm{t}$ expression (H) was an impression of "co-localisation" in the perinuclear region visualised in the merged images (I).

demonstrated an increased expression of Th17 cytokines and chemokines such as IL-17A, IL-17F, IL-22 and CCL20 in active Crohn's disease. ${ }^{16}{ }^{32-35}$

Here, we show significantly increased IL-26 serum levels in patients with Crohn's disease compared with healthy controls. However, overall IL-26 serum levels were rather low, which is probably related to the fact that only less than $1 \%$ of cells in the peripheral blood are Th17 cells. ${ }^{36}$ In contrast, the high number of infiltrating ROR $\gamma$ t-expressing intestinal Th17 cells in active Crohn's disease suggests an important role for this cell type in local tissue inflammation. IL-26-producing Th17 cells are likely to sustain intestinal inflammation since we demonstrate here that IL-26 upregulates the gene transcription of several proinflammatory cytokines such as IL- 8 and TNF $\alpha$ in IECs, while its own expression is upregulated in IBD. A recent study demonstrated that peripheral $T$ cells, which differentiated under the influence of IL-23 and IL-1 $\beta$ to Th17 cells, produce IL-26, supporting Th17 cells as a major source of IL-26 production. ${ }^{4}$ In contrast, IL-23 is mainly produced in ileal dendritic cells. ${ }^{37} \mathrm{We}$ and others recently demonstrated that ileal dendritic cells play a 
major role in the luminal sampling of bacterial pathogens, ${ }^{38}$ thereby potentially linking defects in the antibacterial defence with the pathogenesis of Crohn's disease.

In addition, we demonstrate that IL-26 is functional in IECs. IL-26-induced STAT1/3 activation results in increased SOCS-3 mRNA expression. This confirms our previous studies demonstrating that SOCS-3 is an immediate early transcriptional target of STAT1/3. ${ }^{16} 27$ Interestingly, in Crohn's disease, increased colonic STAT1 phosphorylation and SOCS-3 protein levels were found, ${ }^{39}$ supporting our findings of a proinflammatory role for IL-26 in Crohn's disease. Another study demonstrated in a murine colitis model that SOCS-3 plays a negative regulatory role in STAT3 activation and intestinal inflammation. ${ }^{40}$ In addition, we recently showed that signalling of other IL-10-like cytokines such as IL-22 and the IFN $\lambda$ s IL-28A and IL-29 is abrogated by increased expression of SOCS proteins in hepatic cell lines ${ }^{18} 19{ }^{41}$ and neuroendocrine cells. ${ }^{26}$ This suggests that IL-10like cytokines increase the expression of SOCS-3 and proinflammatory cytokines, while in turn SOCS-3 has a negative feedback on the expression and signalling of these cytokines. Interestingly, we found a similar mechanism for the signalling mediated by IFN $\alpha^{42}$ and IFN $\beta .^{43}$ Moreover, similar to the results of our studies with IL-28A and IL-29, ${ }^{17} 2644$ two other IL-10-related cytokines, IL-26 mediates antiproliferative effects in IECs.

In summary, this is the first report on the role of IL-26 in human disease, particularly IBD. Here, we demonstrate that IECs express the functional IL-26 receptor complex. IL-26 activates STAT1/3, Akt, ERK and SAPK/JNK MAP kinases and upregulates the expression of proinflammatory cytokines and of SOCS-3 mRNA. In addition, IL-26 mRNA expression is upregulated in inflamed colonic lesions of patients with Crohn's disease due to an increased infiltration of IL-26-expressing immune cells including ROR $\gamma$ t-expressing Th17 cells. Colonic IL-26 expression in IBD correlates highly with the expression of IL-22, another Th17 cytokine. However, the functional analysis of IL-26, particularly in murine models of intestinal inflammation, is limited by the fact that the IL-26 gene is not expressed in mice. In conclusion, our data indicate a role for this novel cytokine system in promoting proinflammatory gene transcription, suggesting a role in intestinal inflammation. Considering the recent progress in IBD genetics and the identification of IL23R as an IBD susceptibility gene ${ }^{3031}$ and of $I L 26$ as a susceptibility gene for ulcerative colitis, ${ }^{46}$ IL-26 is probably an important effector cytokine by which Th17 cells contribute to the pathogenesis of IBD.

Acknowledgements: We thank S Pfeiler, A Bedynek, G Spöttl and J Meinecke (University of Munich) for excellent technical support. This work contains parts of the unpublished doctoral thesis of JD at Ludwig-Maximilians-University Munich, Germany. Parts of this paper have been presented at the Annual Meeting of the American Gastroenterological Association and Digestive Disease Week, Los Angeles, May 20-25, 2006 and have been published in abstract form in Gastroenterology 2006; 130 (4, Suppl.2): A696. Additional parts were presented as an oral presentation at the United European Gastroenterology Week in Berlin, Germany, October 21-25, 2006 and were published in abstract form in Gut. SB was supported by grants of the Deutsche Forschungsgemeinschaft (BR 1912/3-1 and 5-1), Else Kröner-Fresenius-Stiftung (Else Kröner-Fresenius Memorial Grant 2005; 60/05//EKMS 05/62), the Ludwig-Demling Grant 2007 of DCCV e.V and Ludwig-Maximilians-University (Excellence Initiative-Investment Funds). JD was supported by the Hochschul- und Wissenschaftsprogramm (HWP) of Ludwig-Maximilians-University Munich, Germany.

Competing interests: None.

Ethics approval: The study was approved by the Ethics Committee of the Medical Faculty of the University of Munich.

\section{REFERENCES}

1. Knappe A, Hor S, Wittmann S, et al. Induction of a novel cellular homolog of interleukin-10, AK155, by transformation of T lymphocytes with herpesvirus saimiri. J Virol 2000;74:3881-7.
2. Sheikh F, Baurin VV, Lewis-Antes A, et al. Cutting edge: IL-26 signals through a novel receptor complex composed of IL-20 receptor 1 and IL-10 receptor 2. J Immunol 2004;172:2006-10.

3. Wolk K, Kunz S, Asadullah K, et al. Cutting edge: immune cells as sources and targets of the IL-10 family members? J Immunol 2002;168:5397-402.

4. Wilson NJ, Boniface K, Chan JR, et al. Development, cytokine profile and function of human interleukin 17-producing helper T cells. Nat Immunol 2007;8:950-7.

5. Harrington LE, Hatton RD, Mangan PR, et al. Interleukin 17-producing CD4+ effector T cells develop via a lineage distinct from the T helper type 1 and 2 lineages. Nat Immunol 2005;6:1123-32.

6. Laurence A, O'Shea J. T(H)-17 differentiation: of mice and men. Nat Immunol 2007:8:903-5.

7. Ivanov, II, McKenzie BS, Zhou L, et al. The orphan nuclear receptor RORgammat directs the differentiation program of proinflammatory IL-17+ T helper cells. Cell 2006; 126:1121-33.

8. Mangan PR, Harrington LE, O'Quinn DB, et al. Transforming growth factor-beta induces development of the T(H)17 lineage. Nature 2006;441:231-4.

9. Liang SC, Tan XY, Luxenberg DP, et al. Interleukin (IL)-22 and IL-17 are coexpressed by Th17 cells and cooperatively enhance expression of antimicrobial peptides. J Exp Med 2006;203:2271-9.

10. Korn T, Bettelli E, Gao W, et al. IL-21 initiates an alternative pathway to induce proinflammatory $\mathrm{T}(\mathrm{H}) 17$ cells. Nature 2007:448:484-7.

11. Furuzawa-Carballeda $\mathbf{J}$, Vargas-Rojas MI, Cabral AR. Autoimmune inflammation from the Th17 perspective. Autoimmun Rev 2007;6:169-75.

12. Yen D, Cheung J, Scheerens $H$, et al. IL-23 is essential for T cell-mediated colitis and promotes inflammation via IL-17 and IL-6. J Clin Invest 2006;116:1310-6.

13. Elson CO, Cong Y, Weaver CT, et al. Monoclonal anti-interleukin 23 reverses active colitis in a T cell-mediated model in mice. Gastroenterology 2007;132:2359-70.

14. Hor S, Pirzer H, Dumoutier L, et al. The T-cell lymphokine interleukin-26 targets epithelial cells through the interleukin-20 receptor 1 and interleukin-10 receptor 2 chains. J Biol Chem 2004;279:33343-51.

15. Igawa D, Sakai M, Savan R. An unexpected discovery of two interferon gamma-like genes along with interleukin (IL)-22 and -26 from teleost: IL-22 and -26 genes have been described for the first time outside mammals. Mol Immunol 2006;43:999-1009.

16. Brand S, Beigel F, Olszak T, et al. IL-22 is increased in active Crohn's disease and promotes proinflammatory gene expression and intestinal epithelial cell migration. Am J Physiol Gastrointest Liver Physiol 2006;290:G827-38.

17. Brand S, Beigel F, Olszak T, et al. IL-28A and IL-29 mediate antiproliferative and antiviral signals in intestinal epithelial cells and murine CMV infection increases colonic IL-28A expression. Am J Physiol Gastrointest Liver Physiol 2005;289:G960-8.

18. Dambacher J, Beigel F, Zitzmann K, et al. IL-22 induced signaling mediates liver cell regeneration and is abrogated by SOCS-1 overexpression (abstract). Gastroenterology 2006; 4(Suppl. 2):A752.

19. Brand S, Zitzmann K, Dambacher J, et al. SOCS-1 inhibits expression of the antiviral proteins $2^{\prime}, 5^{\prime}-\mathrm{OAS}$ and MxA induced by the novel interferon-lambdas IL-28A and IL29. Biochem Biophys Res Commun 2005;331:543-8.

20. Brand S, Dambacher J, Beigel F, et al. Lambda-interferons IL-28A and IL-29 inhibit HCV replication in vitro and hepatic IL-28 mRNA expression is increased in HCV and CMV infection in vivo (abstract). Gastroenterology 2006;130:A835.

21. Brand S, Sakaguchi T, Gu X, et al. Fractalkine-mediated signals regulate cell-survival and immune-modulatory responses in intestinal epithelial cells. Gastroenterology 2002;122:166-77.

22. Dambacher J, Beigel F, Seiderer J, et al. Interleukin 31 mediates MAP kinase and STAT1/3 activation in intestinal epithelial cells and its expression is upregulated in inflammatory bowel disease. Gut 2007:56:1257-65.

23. Muehlhoefer A, Saubermann LJ, Gu X, et al. Fractalkine is an epithelial and endothelial cell-derived chemoattractant for intraepithelial lymphocytes in the small intestinal mucosa. J Immunol 2000;164:3368-76.

24. Eichhorst ST, Krueger A, Muerkoster S, et al. Suramin inhibits death receptorinduced apoptosis in vitro and fulminant apoptotic liver damage in mice. Nat Med 2004;10:602-9.

25. Brand S, Dambacher J, Beigel F, et al. CXCR4 and CXCL12 are inversely expressed in colorectal cancer cells and modulate cancer cell migration, invasion and MMP-9 activation. Exp Cell Res 2005;310:117-30.

26. Zitzmann K, Brand S, Baehs S, et al. Novel interferon-lambdas induce antiproliferative effects in neuroendocrine tumor cells. Biochem Biophys Res Commun 2006;344:1334-41.

27. Auernhammer CJ, Bousquet C, Melmed S. Autoregulation of pituitary corticotroph SOCS-3 expression: characterization of the murine SOCS-3 promoter. Proc Natl Acad Sci USA 1999;96:6964-9.

28. Neurath MF. IL-23: a master regulator in Crohn disease. Nat Med 2007:13:26-8.

29. Bouma G, Strober W. The immunological and genetic basis of inflammatory bowel disease. Nat Rev Immunol 2003:3:521-33.

30. Duerr RH, Taylor KD, Brant SR, et al. A genome-wide association study identifies IL23R as an inflammatory bowel disease gene. Science 2006;314:1461-3.

31. Glas J, Seiderer J, Wetzke M, et al. rs1004819 is the main disease-associated IL23R variant in German Crohn's disease patients: combined analysis of IL-23R, CARD15, and OCTN1/2 variants. PLOS ONE 2007;2:e819.

32. Schmechel S, Konrad A, Diegelmann J, et al. Linking genetic susceptibility to Crohn's disease with Th17 cell function: IL-22 serum levels are increased in Crohn's disease and correlate with disease activity and IL-23R genotype status. Inflamm Bowel Dis 2008;14:204-12. 
33. Seiderer J, Elben I, Diegelmann J, et al. Role of the novel Th17 cytokine IL-17F in inflammatory bowel disease (IBD): upregulated colonic IL-17F expression in active Crohn's disease and analysis of the IL-17F p.His161Arg polymorphism in IBD. Inflamm Bowel Dis 2008:14:437-445.

34. Fujino S, Andoh A, Bamba S, et al. Increased expression of interleukin 17 in inflammatory bowel disease. Gut 2003;52:65-70.

35. Brand S, Olszak T, Beigel F, et al. Cell differentiation dependent expressed CCR6 mediates ERK-1/2, SAPK/JNK, and Akt signaling resulting in proliferation and migration of colorectal cancer cells. J Cell Biochem 2006;97:709-23.

36. Annunziato F, Cosmi L, Santarlasci V, et al. Phenotypic and functional features of human Th17 cells. J Exp Med 2007;204:1849-61.

37. Becker C, Wirtz S, Blessing M, et al. Constitutive p40 promoter activation and IL-23 production in the terminal ileum mediated by dendritic cells. J Clin Invest 2003;112:693-706

38. Niess JH, Brand S, Gu X, et al. CX3CR1-mediated dendritic cell access to the intestinal lumen and bacterial clearance. Science 2005;307:254-8.

39. Schreiber S, Rosenstiel P, Hampe J, et al. Activation of signal transducer and activator of transcription (STAT) 1 in human chronic inflammatory bowel disease Gut 2002;51:379-85.
40. Suzuki A, Hanada T, Mitsuyama K, et al. CIS3/SOCS3/SSI3 plays a negative regulatory role in STAT3 activation and intestinal inflammation. J Exp Med 2001;193:471-81.

41. Brand S, Dambacher J, Beigel F, et al. IL-22 mediated liver cell regeneration is abrogated by SOCS-1/3 overexpression in vitro. Am J Physiol Gastrointest Liver Physiol 2007;292:G1019-28.

42. Vlotides G, Sorensen AS, Kopp F, et al. SOCS-1 and SOCS-3 inhibit IFN-alphainduced expression of the antiviral proteins 2,5-OAS and MxA. Biochem Biophys Res Commun 2004;320:1007-14

43. Zitzmann K, Brand S, De Toni EN, et al. SOCS1 silencing enhances antitumor activity of type I IFNs by modulating pro-apoptotic pathways in neuroendocrine tumor cells. Cancer Res 2007;67:5025-32.

44. Brand S, Beigel F, Olszak T, et al. The novel lambda-interferons IL-28A and IL-29 mediate proinflammatory, antiproliferative, and antiviral signals in intestinal epithelial cells. Gastroenterology 2005;129:371.

45. Brand S, Beigel F, Dambacher J, et al. The novel cytokines IL-28A and IL-29 exhibit antiproliferative and antiviral properties in liver cells (abstract). Gastroenterology 2005; 128:A751.

46. Silverberg MS, Cho JH, Riouk JD, et al. Ulcerative colitis-risk loci on chromosomes $1 \mathrm{p} 36$ and 12q15 found by genome-wide association study. Nat Genet 2009;41:216-20.

\section{Editor's quiz: GI snapshot}

\section{Atypical dyspepsia}

\section{CLINICAL PRESENTATION}

A 68-year-old man with a history of dyspepsia and hiatus hernia presented with $15 \mathrm{~kg}$ weight loss with occasional nausea and vomiting episodes over the previous year. He was not taking any regular medication. He underwent gastroscopy, colonoscopy and barium swallow 1 year earlier to investigate change in bowel habit and dyspepsia. These tests revealed hiatus hernia and a non-specific motility disorder of the distal oesophageal segment. Clinical examination was unremarkable.

Blood tests were all normal. An ultrasound scan of the abdomen was normal and repeat gastroscopy again showed only hiatus hernia. A chest $x$ ray, which was performed in view of weight loss and smoking history, was normal.

Symptoms initially improved with regular domperidone; however, vomiting became more frequent and occurred in association with abdominal pain.

A repeat ultrasound scan of the abdomen was arranged (fig 1).

\section{QUESTION}

What is the diagnosis?

See page 1288 for the answer.

\section{R Palmer, ${ }^{1}$ F MacLeod, ${ }^{2} \mathrm{~J}$ Marshall ${ }^{3}$}

${ }^{1}$ Department of Gastroenterology, Oxford Radcliffe Hospital NHS Trust, John Radcliffe Hospital, Oxford, UK; ${ }^{2}$ Department of Radiology, Oxford Radcliffe Hospital NHS Trust,

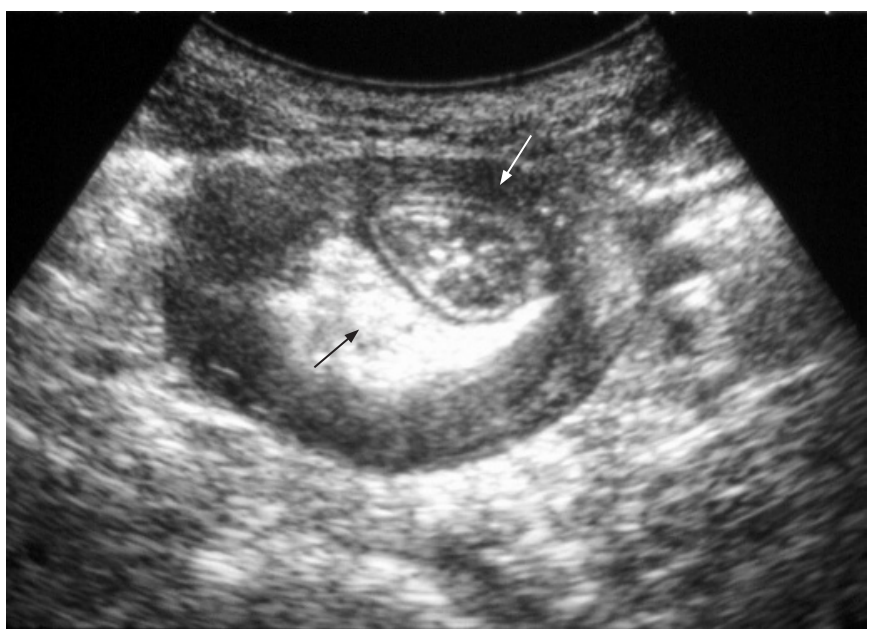

Figure 1 Ultrasound of the abdomen. The small bowel can be seen with its accompanying echogenic mesenteric fat (black arrow). There is an abnormal surrounding darker ring (white arrow).

Horton General Hospital, Banbury, UK; ${ }^{3}$ Department of Gastroenterology, Oxford Radcliffe Hospital NHS Trust, Horton General Hospital, Banbury, UK

Correspondence to: Dr R Palmer, Department of Gastroenterology, Oxford Radcliffe Hospital NHS Trust, John Radcliffe Hospital, Headley Way, Headington, Oxford OX3 9DU, UK; rebeccapalmer@doctors.net.uk

Competing interests: None.

Patient consent: Obtained.

Gut 2009;58:1217. doi:10.1136/gut.2008.164723 


\section{The role of the novel Th17 cytokine IL-26 in} intestinal inflammation

J Dambacher, F Beigel, K Zitzmann, et al.

Gut 2009 58: 1207-1217 originally published online May 15, 2008

doi: 10.1136/gut.2007.130112

Updated information and services can be found at:

http://gut.bmj.com/content/58/9/1207.full.html

\section{These include:}

Data Supplement

References

Email alerting service
"Web only appendix"

http://gut.bmj.com/content/suppl/2009/08/07/58.9.1207.DC1.html

This article cites 46 articles, 18 of which can be accessed free at: http://gut.bmj.com/content/58/9/1207.full.html\#ref-list-1

Article cited in:

http://gut.bmj.com/content/58/9/1207.full.html\#related-urls

Receive free email alerts when new articles cite this article. Sign up in the box at the top right corner of the online article.

\section{Notes}

To request permissions go to:

http://group.bmj.com/group/rights-licensing/permissions

To order reprints go to:

http://journals.bmj.com/cgi/reprintform

To subscribe to BMJ go to:

http://group.bmj.com/subscribe/ 